\title{
Insulin Antibodies Prevent Insulin-Receptor Interactions
}

\author{
R. de Pirro, A. Fusco, L. Spallone, R. Magnatta, and R. Lauro \\ 2 Clinica Medica, Policlinico Umberto I ${ }^{\circ}$, Roma, Italy
}

Summary. The study was carried out to investigate whether insulin bound to antibody is able to bind the insulin receptor of target tissues. Three specific rabbit anti-insulin sera as well as sera from eight diabetic patients with insulin antibodies were incubated, free of insulin, with labelled insulin for $48 \mathrm{~h}$ at $4{ }^{\circ} \mathrm{C}$; following incubation labelled insulin was employed in binding experiments on monocytes, erythrocytes and placenta membranes. Using rabbit sera, receptor binding was absent when insulin was totally combined with antibody, and appeared in increasing amounts as the percentage of free insulin increased to reach a maximum when no insulin was combined with antibody. The same experiment using sera from diabetic patients showed a close negative relationship $(\mathrm{r}=0.95)$ between the amount of insulin bound to the antibody and the amount bound to receptors. The influence of the insulin-antibody complex on the insulin receptor interaction was evaluated by exposing the insulin-antibody complex to the receptor in $\mathrm{pH}$, temperature and competition-inhibition curve experiments. The complex had no effect on receptor affinity or on the $\mathrm{pH}$ and temperature relationship influence with insulin-receptor interaction. The findings suggest that insulin resistance in the presence of insulin antibodies is due only to an alteration occurring before the interaction of insulin with its receptor, and demonstrate that the insulin-antibody complex does not influence the insulin receptor interaction.

Key words: Insulin, insulin antibody, insulin receptor, insulin resistance.

It has become increasingly apparent that certain clinical disorders and metabolic states are associated with insulin resistance. Insulin initiates its effects by interacting with receptors located on the plasma membrane $[1-3]$ and altered insulin receptor interaction may be responsible for hormone resistance [4-14].

Insulin resistance due to insulin antibodies may thus be considered a pre-receptor phenomenon [15, 16] with insulin bound to antibody being unavailable for receptor binding $[15,16]$.

In the present study we have examined the effect of circulating insulin antibodies on insulin-receptor interaction.

\section{Materials and Methods}

${ }^{125} \mathrm{I}$-porcine insulin $(120-150 \mu \mathrm{Ci} / \mu \mathrm{g})$ was purchased from Sorin, Italy, porcine insulin from Organon-Holland, and charcoal (Norit A) from Fisher, USA.

Specific insulin antibodies raised in rabbits were kindly donated by Dr. G. Tamburrano, Rome and sera from diabetic patients with insulin antibodies by Dr. M. Iavicoli, Rome.

\section{Preparation of Insulin-free Serum}

Prior to use sera were treated, unless otherwise mentioned, with $1 \%$ dextran coated charcoal at $\mathrm{pH} 3.5$ according to Dixon [17], to yield an insulin-free preparation; after this procedure the $\mathrm{pH}$ of sera was immediately restored to 7.4 by addition of sodium hydroxide. Approximately $94 \%$ of insulin was removed by this treatment.

\section{Erythrocyte, Leukocyte and Placental Preparation}

$100 \mathrm{ml}$ of venous blood was drawn from normal medical personnel into vials containing $0.129 \mathrm{~mol} / \mathrm{l}$ sodium citrate. The mononuclear leukocytes and erythrocytes were separated from the other components using a Ficoll-Angiografin gradient $[18,19]$, according to the procedure of Boyum [20]. They were then suspended in $100 \mathrm{mmol} /$ 1 Hepes buffer containing $1 \mathrm{~g} / 100 \mathrm{ml}$ bovine serum albumin (BSA) (pH 7.8). The mononuclear cell preparation contained $85 \%$ lymphocytes and $15 \%$ monocytes [18]; since it has been demonstrated that insulin binding depends primarily upon monocytes [21, 22] 

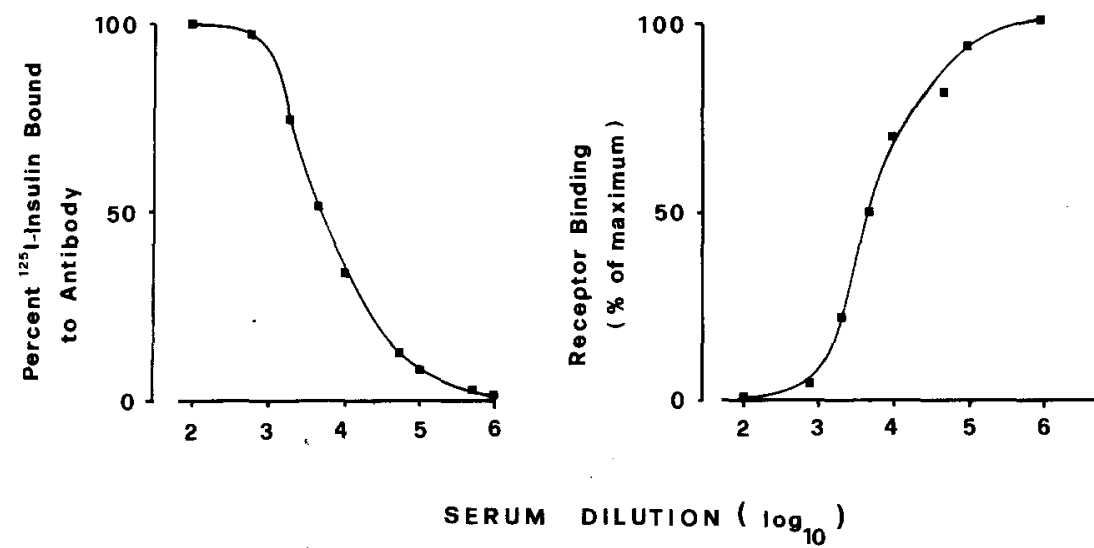

Fig. 1. Effect of insulin antibody dilution on percent labelled insulin bound to antibody (left) and on subsequent binding of labelled insulin $(0.2 \mathrm{ng} / \mathrm{ml})$ on $4 \times 10^{6}$ monocytes $/ \mathrm{ml}$ (right). Insulin antibodies were from a rabbit immunized against porcine insulin; sera from two other rabbits gave similar results. Maximal receptor binding (i. e.; $100 \%$ ) was evaluated using labelled insulin pre-incubated for $48 \mathrm{~h}$ at $4{ }^{\circ} \mathrm{C}$ in Hepes buffer and was $2.4 \%$ of total radioactivity

SERUM DILUTION $\left(\log _{10}\right)$

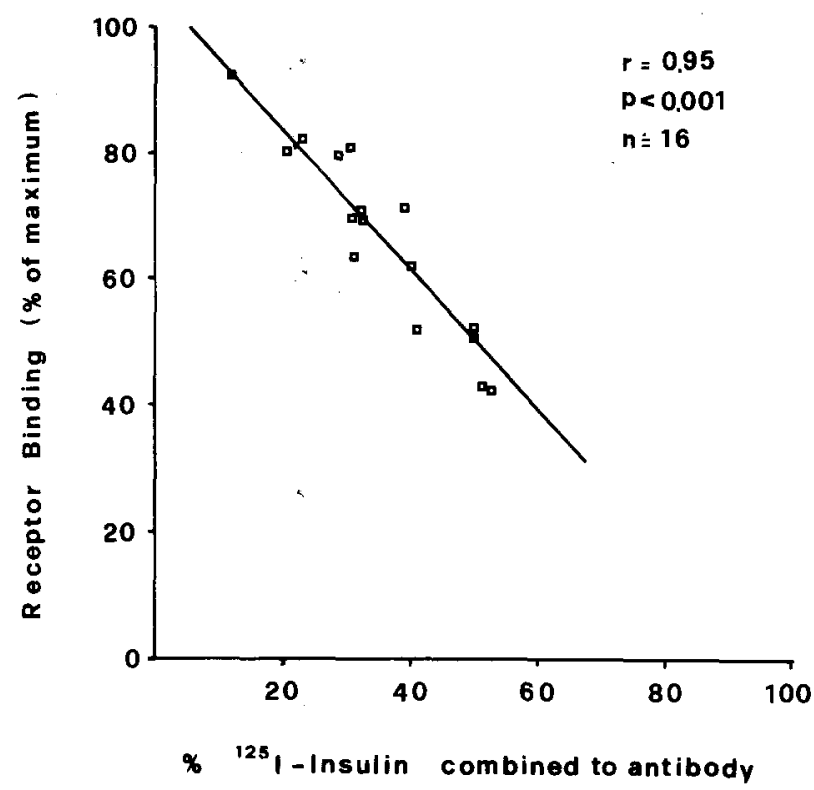

Fig. 2. Relationship between percent labelled insulin combined to antibody and subsequent binding of labelled insulin $(0.2 \mathrm{ng} / \mathrm{ml})$ to placenta membranes $(150 \mu \mathrm{g} / \mathrm{ml})$. Maximal receptor binding (i. e. $100 \%$ ) was evaluated using labelled insulin pre-incubated for $48 \mathrm{~h}$ at $4{ }^{\circ} \mathrm{C}$ in sodium phosphate buffer and was $31.2 \%$ of total radioactivity. Values were obtained using sera from eight diabetic patients with insulin antibodies, at two different dilutions. (five-, twenty- or fifty-fold)

results refer only to the latter cells. In erythrocyte preparations white cells were undetectable.

Normal human placenta collected immediately after delivery, trimmed of amnion and chorion, was washed in $0.25 \mathrm{~mol} / 1$ cold sucrose and homogenized in the same solution $(1: 3 ; \mathrm{w}: \mathrm{v})$ with an Ultra-Turrax (three cycles, $30 \mathrm{~s}$ ). Membranes were isolated by differential centrifugation according to Cuatrecasas [23] and suspended in $0.05 \mathrm{~mol} / \mathrm{l}$ sodium phosphate buffer containing $0.5 \mathrm{~g} / \mathrm{l}$ BSA ( $\mathrm{pH} 7.6$ ) [24]. $1 \mathrm{~g}$ of tissue yielded $1 \mathrm{mg}$ of membranes.

\section{Pre-incubation of Labelled Insulin with Serum}

Labelled insulin $(2 \mathrm{ng} / \mathrm{ml})$ was exposed to rabbit and human sera and to the same buffer used in binding studies (i. e. Hepes for cells and sodium phosphate for membranes) for $48 \mathrm{~h}$ at $4{ }^{\circ} \mathrm{C}$. Preincuba- tion produced steady-state equilibrium in 15-36 h depending upon the antibody and the dilution used.

Following incubation $0.1 \mathrm{ml}$ were employed in receptor binding studies and $0.5 \mathrm{ml}$ to evalute the amount of insulin bound to antibody; the percentage bound was determined by $1 \%$ dextran coated charcoal precipitation [17].

\section{Binding Studies}

Labelled insulin $(0.2 \mathrm{ng} / \mathrm{ml})$ previously exposed to serum or buffer $\left(48 \mathrm{~h}\right.$ at $\left.4^{\circ} \mathrm{C}\right)$ was incubated with monocytes $\left(4 \times 10^{6} / \mathrm{ml}, 100 \mathrm{~min}\right.$ at $\left.15^{\circ} \mathrm{C}\right)$, erythrocytes $\left(3 \times 10^{9} / \mathrm{ml}, 210 \mathrm{~min}\right.$ at $\left.15^{\circ} \mathrm{C}\right)$ or placental membranes $\left(150 \mu \mathrm{g} / \mathrm{ml}, 60 \mathrm{~min}\right.$ at $\left.24^{\circ} \mathrm{C}\right)$ in a final volume of $0.5 \mathrm{ml}$. Following incubation bound and free insulin were separated by centrifugation $[18,19,24]$. Non specific binding, defined as the amount of radioactivity "bound" in the presence of $7 \mu \mathrm{mol} / \mathrm{l}$ of native insulin was subtracted and found to represent $0.7-1 \%$ of total radioactivity $[18,19,24]$. Competition-inhibition curves were performed incubating cells or membranes with labelled insulin and varying amounts of native insulin. Insulin degradation was measured by $10 \%(v / v)$ trichloracetic acid precipitation. Labelled insulin incubated in buffer was employed to assay the insulin specifically bound to receptor and the value obtained was taken as maximal binding (i. e. $100 \%$ ). The effect on insulin binding of preincubation with serum is expressed as the percentage of this value.

\section{Statistical Analysis}

Linear regression analysis was used to evaluate the relationship between the percentage of insulin bound to antibody and that bound to receptor.

\section{Results}

A preliminary series of experiments, using three different rabbit sera, was carried out to evaluate whether insulin bound to antibody reacts with its receptors.

Receptor binding was absent when insulin was totally combined with antibody and progressively increased as the percentage of free ${ }^{125} \mathrm{I}$-insulin rose (Fig. 1).

A subsequent series of experiments was performed using sera from diabetic patients with insulin 


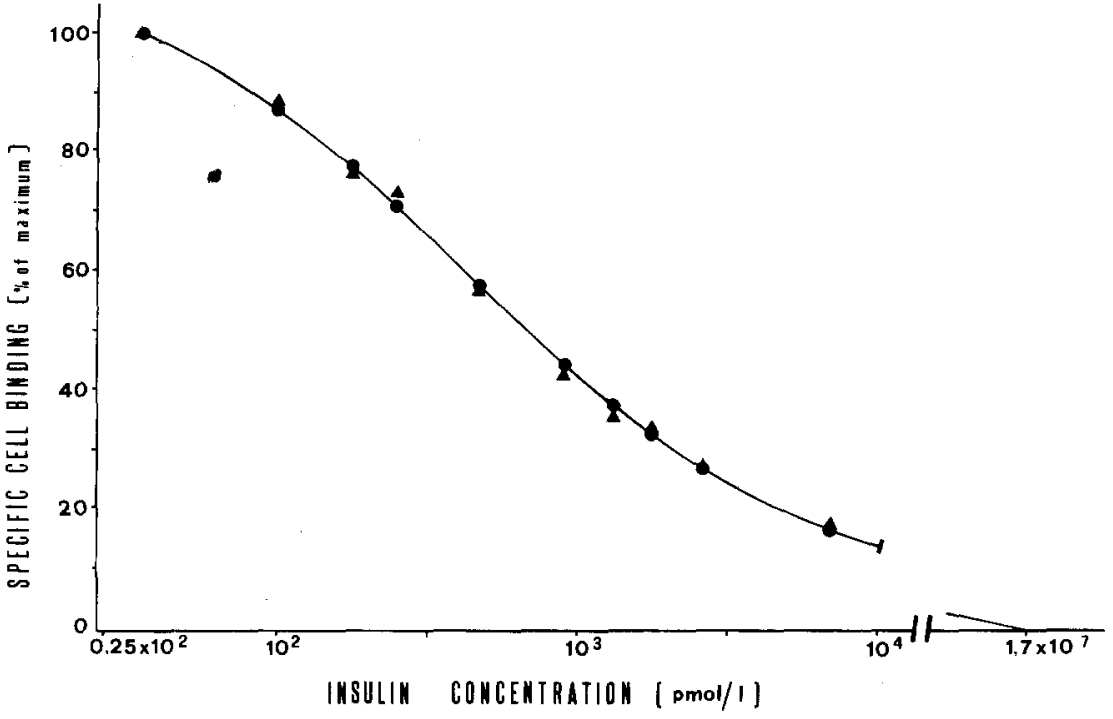

Fig. 3. Competition-inhibition effect of native insulin on labelled insulin $(0.2 \mathrm{ng} / \mathrm{ml})$ binding on $3 \times 10^{9}$ erythrocytes $/ \mathrm{ml}$. Labelled insulin was pre-incubated with Hepes buffer (-) or human insulin antibodies ( $\mathbf{A}$ ) for $48 \mathrm{~h}$ at $4^{\circ} \mathrm{C}$; specific cell binding is the percentage of labelled insulin bound at any given concentration of total insulin $(\mathrm{B} / \mathrm{T})$ minus the percentage bound at the concentration of $7 \mu \mathrm{mol} / 1$ (nonspecific binding)

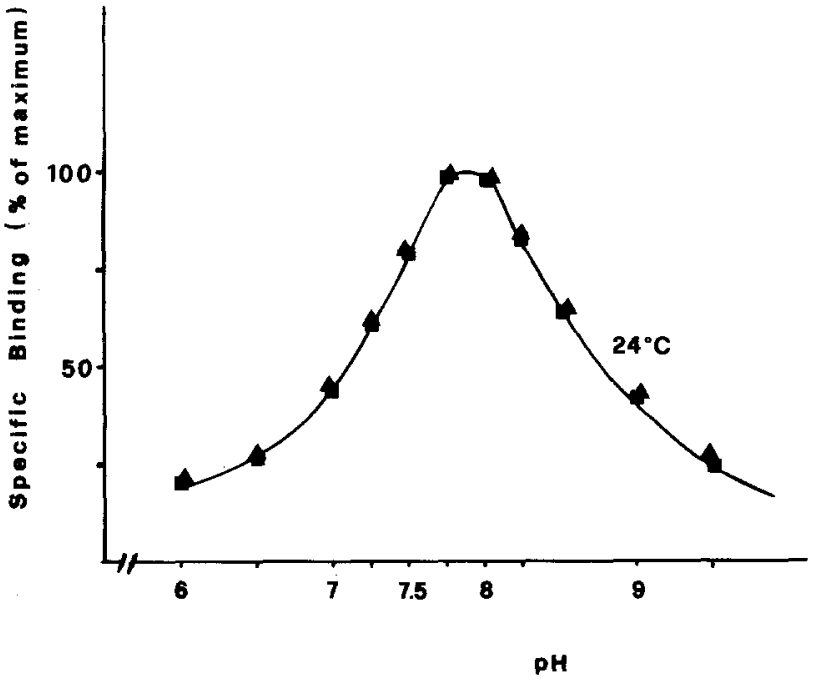

Fig. 4. $\mathrm{pH}$ effect on labelled insulin $(0.2 \mathrm{ng} / \mathrm{ml})$ binding (cpm $\times$ $10^{-2}$ ) on $200 \mu \mathrm{l}$ of placenta membranes $(150 \mu \mathrm{g} / \mathrm{ml})$. Labelled insulin was pre-incubated with sodium phosphate buffer (- $)$ or human insulin antibodies ( binding, radioactivity bound in the presence of $7 \mu \mathrm{mol} / 1$ of native insulin, was substracted

antibodies, diluted 5-50 fold. These sera bound a percentage of labelled insulin thus inducing a reduction in binding to receptor. A close negative relationship was demonstrated $(r=0.95)$ between the percentage of insulin bound to antibody and bound to receptors (Fig. 2).

Using sera treated with neutral charcoal, instead of acid charcoal, the percentage of insulin bound to antibody was slightly lower. Conversely a more marked decrease in receptor binding was observed probably due to a native insulin displaced from antibody following pre-incubation with labelled insulin.
Insulin degradation, measured at the end of each incubation with receptors (monocytes, erythrocytes, placenta membranes) was $3-5 \%$.

Using sera from diabetic patients on oral therapy (whose fasting insulin levels ranged from $18-12 \mu \mathrm{U} /$ $\mathrm{ml}$ ) no insulin was bound to serum components and pre-incubation failed to induce any variation in insulin binding on receptors.

The influence of the insulin antibody complex on the insulin receptor interaction was evaluated. Labelled insulin was exposed to rabbit or human sera to obtain combination with antibody from 25 to $70 \%$. This was used to examine $\mathrm{pH}$ and competition-inhibition curves and temperature studies. Competitioninhibition (Fig. 3), pH (Fig. 4) and temperature dependence curves of insulin binding (Fig. 5) were not influenced by the presence of the insulin antibody complex in the medium. All experiments were performed either with monocytes, erythrocytes or placenta membranes and results from the different tissues were identical.

\section{Discussion}

The data presented clearly demonstrate that insulin combined with antibody does not react with insulin receptors and that the insulin antibody complex does not influence the insulin receptor. The proportion of insulin combined with antibody correlated closely with the percentage of insulin receptor binding; furthermore the presence of the insulin antibody complex in the incubation medium did not influence receptor affinity or the $\mathrm{pH}$ and temperature characteristics of the reaction. It is noteworthy that the decrease in binding was not due to insulin degrada- 


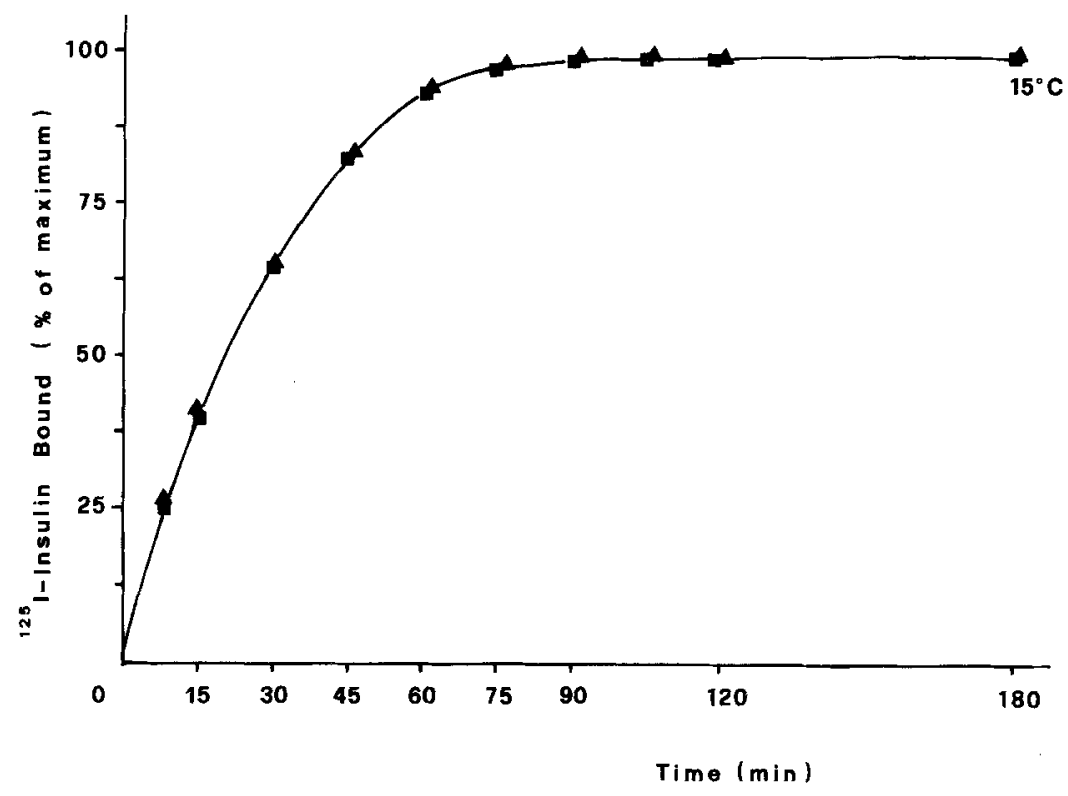

Fig. 5. Time and temperature dependence of labelled insulin $(0.2 \mathrm{ng} / \mathrm{ml})$ binding on $8 \times 10^{6}$ monocytes $/ \mathrm{ml}$. Labelled insulin was pre-incubated with Hepes buffer (-—) or human antibodies ( $\boldsymbol{A} \boldsymbol{\Delta}$ ) for $48 \mathrm{~h}$ at $4{ }^{\circ} \mathrm{C}$. Nonspecific binding (radioactivity bound in the presence of $7 \mu \mathrm{mol} / \mathrm{l}$ of native insulin) was subtracted. The same experiment performed at $24^{\circ} \mathrm{C}$ did not show any difference in time-course presented by labelled insulin pre-incubated in buffer or with insulin antibodies

tion, since this was very low and that the amount of labelled insulin used was within the physiologic range $(\sim 5 \mu \mathrm{U} / \mathrm{ml})$.

The phenomenon occurred with rabbit and human immunoglobulins but not with sera from patients without insulin antibodies, thus confirming that it does not depend upon the source of antibodies or upon unknown components of diabetic sera. Furthermore, the phenomenon occurred using sera treated with neutral charcoal making it unlikely that alterations in serum components produced by acid treatment are responsible.

All experiments were performed at sub-physiological temperatures $\left(15^{\circ} \mathrm{C}\right.$ for monocytes and erythrocytes, and $24^{\circ} \mathrm{C}$ for placenta membranes) as insulin is known to be rapidly degraded at $37^{\circ} \mathrm{C}$ and we assume that the influence of insulin antibodies on insulin-receptor binding also occurs at physiological temperatures.

Recently Kahn et al. [25] demonstrated that highly diluted anti-insulin antibodies added after binding of insulin to its receptors enhanced insulin stimulated adipocyte glucose oxidation.

In view of the different experimental conditions it is not possible to make a direct comparison between our results and those of Kahn. These authors did however observe an effect of added insulin antibodies to decrease insulin action possibly analogous to the reduction in insulin binding noted in our experiments.

Monocytes, erythrocytes and placenta membranes were employed since these are the only human tissues with insulin receptors which may be obtained without biopsy. The fact that results were very similar in all tissues examined suggests that the effects observed are applicable to other target tissues.

In diabetic patients insulin antibodies are induced only after exogenous insulin injections [26] although occasional patients have insulin antibodies, without having had previous insulin injections $[27,28]$. The present data indicate that insulin antibodies may theoretically contribute to the insulin resistance shown by some patients thus confirming previous hypotheses $[15,16]$. Kahn's results, however suggest that anti-insulin antibodies might also potentially enhance insulin action [25]. Further physiological experiments are necessary to resolve this question.

Authors' note: Since submitting this paper Shechter et al. [29] have shown that anti-insulin antibodies enhance insulin binding on liver membranes and fibroblasts but not on adipocytes, thus suggesting that tissue specific phenomena may occur in the presence of antibodies.

Acknowledgements. We are grateful to Dr. Ronald Kahn for helpful discussions and to Mr. Danilo Minelli for skilfull technical assistance. This study was performed in part with a grant from ISIS, sezione scientifica.

\section{References}

1. Cuatrecasas P (1974) Membrane receptors. Annu Rev Biochem 43: 169-214

2. Roth J (1973) Peptide hormone binding to receptors: a review of direct studies in vitro. Metabolism 22: 1059-1073

3. Kahn CR (1976) Membrane receptors for hormones and neurotransmitters. J Cell Biol 70: 261-286

4. Olefsky JM (1976) Decreased insulin binding to adipocytes and circulating monocytes from obese subjects. J Clin Invest 57: $1165-1172$ 
5. Olefsky JM (1976) The insulin receptor: its role in insulin resistance of obesity and diabetes. Diabetes 25: 1154-1162

6. Beck-Nielsen H, Pedersen O, Bagger JP, Sørensen NS (1976) The insulin receptor in normal and obese persons. Acta Endocrinol (Kbh) 83: 565-575

7. Flier JS, Kahn CR, Roth J, Bar RS (1975) Antibodies that impair insulin receptor binding in an unusual diabetic syndrome with severe insulin resistance. Science 190: 63-65

8. Bar RS, Levis WR, Rechler MM, Harrison LC, Siebert C, Podskalny J, Roth J, Muggeo M (1978) Extreme insulin resistance in ataxia telangiectasia. N Engl J Med 298: 1164-1171

9. Oseid S, Beck-Nielsen H, Pedersen O, Søvik O (1977) Decreased binding of insulin to its receptor in patients with congenital generalized lipodystrophy. N Engl J Med 296: 245-248

10. Goldfine ID, Kahn CR, Neville DM jr, Roth J, Garrison MM, Bates RW (1973) Decreased binding of insulin to its receptors in rats with hormone induced insulin resistance. Biochem Biophys Res Commun 53: 852-857

11. Roth J, Kahn CR, Lesniak MA, Gordon P, De Meyts P, Megyesi K, Neville DM jr, Gavin JR, Soll AH, Freychet P, Goldfine ID, Bar RS, Archer JA (1975) Receptors for insulin, NSILA-S and growth hormone applications to disease states in man. Recent Prog Horm Res 31: 95-139

12. Beck-Nielsen $H$ (1978) The pathogenic role of an insulinreceptor defect in diabetes mellitus. Diabetes 27: 1175-1181

13. Baxter D, Stanton K, Lazarus NR, Keen H (1978) The relationship between insulin and adipocyte insulin receptors during treatment of human obesity. Eur J Clin Invest 8: 361-376

14. Muggeo M, Bar RS, Roth J, Kahn CR, Gorden P (1979) The insulin resistance in acromegaly: Evidence for two alterations in the insulin receptor on circulating monocytes. J Clin Endocrinol Metab 48: 17-25

15. Flier JS, Kahn CR, Roth J (1979) Receptors, antireceptor antibodies and mechanisms of insulin resistance. $\mathrm{N}$ Engl J Med 300: $413-419$

16. Kuzuya H, Blix PM, Horwitz DL, Steiner DF, Rubenstein AH (1977) Determination of free and total insulin and C-peptide in insulin-treated diabetics. Diabetes 26: 22-29

17. Dixon K (1974) Measurement of antibodies to insulin in serum. Clin Chem 20: 1274-1281

18. De Pirro R, Bertoli A, Greco AV, Gelli AS, Lauro R (1979) The effect of food intake on insulin receptor in man. Acta Endocrinol (Kbh) 90: 473-480
19. Lauro R, Greco AV, Bertoli A, Fusco A, Spallone L, Magnatta $R$, De Pirro R (1979) A study on insulin receptors of human erythrocytes. LAB, J Res Lab Med 6: 379-384

20. Boyum A (1968) Separation of leukocytes from blood and bone marrow. Scand J Clin Invest 21 (Suppl 97): 77-89

21. Beck-Nielsen H, Pedersen O, Kragballe K, Sørensen NS (1979) The monocyte as a model for the study of insulin receptors in man. Diabetologia 13: 563-569

22. Schwartz RH, Bianco AR, Handwerger BS, Kahn CR (1975) Demonstration that monocytes rather than lymphocytes are the insulin binding cells in preparation of human peripheral blood mononuclear leukocytes preparation: implication for studies of insulin-resistance states in man. Proc Natl Acad Sci USA 72: $474-478$

23. Cuatrecasas $P$ (1972) Isolation of the insulin receptor of liver and fat-cell membranes. Proc Natl Acad Sci USA 69: 318-322

24. De Pirro R, Lauro R, Gelli AS, Bertoli A, Musiani P (1979) Specificities of rabbit anti-human insulin receptor antibodies. J Clin Lab Immunol 2: 27-30

25. Kahn CR, Baird KL, Jarrett DB, Flier J (1978) Direct demonstration that receptor crosslinking or aggregation is important in insulin action. Proc Natl Acad Sci USA 75: 4209-4213

26. Christy M, Deckert T, Nerup J (1978) Immunity and autoimmunity in diabetes mellitus. Clin Endocrinol Metab 7: 32-69

27. Følling I, Norman N (1972) Hyperglycemia, hypoglycemic attacks and production of anti-insulin antibodies without previous known immunization. Diabetes 21: 814-826

28. Ohneda A, Matsuda K, Sato M, Yamagata S, Sato T (1974) Hypoglycemia due to apparent autoantibodies to insulin. Diabetes 23: $41-50$

29. Shechter Y, Chang K, Jacobs S, Cuatrecasas P (1979) Modulation of binding and bioactivity of insulin by anti-insulin antibody: Relation to possible role of receptor self-aggregation in hormone action. Proc Natl Acad Sci USA 76: 2720-2724

Received: May 30, 1979,

and in revised form: December 6, 1979

Roberto de Pirro, M. D.

2^ Clinica Medica

Policlinico Umberto $I^{\circ}$

Viale del Policlinico

I-00161 Roma

Italy 